\title{
IR EMBORA OU FICAR \\ UM ESTUDO SOBRE PARENTESCO, PATRIMÔNIO E GÊNERO A PARTIR DE EXPERIÊNCIA ETNOGRÁFICA EM FAMÍLIAS DE CAMADAS MÉDIAS EM PORTO ALEGRE, RS ${ }^{1}$
}

Anelise dos Santos Gutterres

\section{Introdução}

Este ensaio busca discutir a categoria família a partir da experiência etnográfica com duas mulheres integrantes e descendentes de famílias de classes médias e altas de Porto Alegre pertencentes a segmentos sociais intelectualizados e cosmopolitas - e dos arranjos de suas estruturas de parentesco acionadas no processo de desocupação de suas casas oriundas de "herança de família".

Viso discutir, na perspectiva de uma antropologia urbana (VELHO, 1987) e do processo de realização da etnografia, as relações de gênero, parentesco e família em camadas médias urbanas. Preocupada em compreender a dinâmica dos papéis sociais, sexuais e de gênero da mulher nestes segmentos sociais, e no interior de suas estruturas de parentesco, a intenção é pensar a transformação do lugar social dessas mulheres na família, no momento da sua troca de casa, dado em função da sua troca de estado: de casadas a viúvas ou de casadas a "deixadas pelo marido". Integrando essa dinâmica, trago reflexões de gênero ligadas a condição da etnógrafa, mulher, como provocadora da interação que resulta nos relatos e entrevistas dispostos no corpo desse ensaio.

Tendo em vista as discussões de maternidade, gênero, família e novas tecnologias de reprodução provocadas pelos seminários do tópico do curso de mestrado do Programa de PósGraduação em Antropologia Social da UFRGS, intitulado Novas e velhas tecnologias de reprodução, ministrado pela Profa, Dra. Claudia Fonseca, busco contribuir para o campo temático dos estudos da antropologia da família, num diálogo com os estudos e textos lidos nessa ocasião - de diferentes momentos dos estudos de parentesco e de uma antropologia feminista de parentesco.

Para essa aventura nos deteremos nos estudos clássicos de parentesco e família, a partir de Claude Lèvi-Strauss e sua obra clássica As Estruturas Elementares do Parentesco (2003), de

\footnotetext{
1 Monografia apresentada como requisito à conclusão do Tópico Especial V de Antropologia: Novas (e velhas) tecnologias de reprodução, do Programa de Pós-Graduação em Antropologia Social Professor Dra. Claudia Fonseca
} 
Pierre Bourdieu La Famille Comme Catégorie Réalisée (1993:32) onde o autor ressalta a família como "une réalité transcendante à ses membres, um personnage traspersonnel doté d'une vie et d'um esprit communs et d'une vision particulière du monde”. Dialogaremos também com os estudos de Jane Carsten a partir da introdução do conhecido Cultures of relatedness: new approaches to the study of kinship (2000:17) nos aproximando da sua concepção de parentesco como processo.

Visando também a discussão trazida pelas pesquisas de Claudia Fonseca (1997; 2004), junto às classes populares, em Porto Alegre, buscaremos travar um diálogo pela relevância da categoria família e da casa para o estabelecimento e o sucesso na "circulação de crianças" e sua relação com as estruturas de parentesco e os papéis familiares na contemporaneidade. Com intuito de problematizar o tema da herança em camadas médias urbanas no que tange ao lugar da prole nas estruturas de parentesco dessas famílias.

$\mathrm{Na}$ perspectiva da construção da família moderna, conforme a genealogia da família moderna traçada por Philippe Ariès em A História Social da Criança e da Família (1986), e refletindo, no cômputo dos dados etnográficos oriundos do trabalho de campo com os sujeitos de minha pesquisa de mestrado, recorro aos estudos de narrativa (RICOEUR, 1991) para pensar a recorrência da categoria household (HARRIS, 1983:152) na construção e na transformação dos papéis sociais (SALEM, 1980; 2008) das mulheres no interior da dinâmica das estruturas de parentesco nas famílias pesquisadas.

Tendo a "casa da família" como fator relevante na construção e manutenção de uma memória familiar, que sustenta e agencia, valores ético-morais associados a determinados estilos de vida e visões de mundo (VELHO, 1987), o desaparecimento deste patrimônio é responsável pela instalação do drama do esquecimento e da lembrança de um legado a ser transmitido para as gerações futuras pela geração de mulheres por mim estudadas. O tema da morte da "casa de família", sua destruição parcial ou total, momento em que a experiência etnográfica ocorreu, situa esta pesquisa no âmbito dos estudos de memória, trajetórias sociais e narrativas biográficas (ECKERT \& ROCHA, 2005) em sociedades complexas. Considero aqui a possibilidade de que tal drama comportaria, nos jogos da memória agenciadores da lembrança e do esquecimento acionados pelas mulheres guardiãs-da-memória, questões singulares de re-orientação de projetos de vida, orientados ora pela noção de indivíduo (VELHO, 1987), ora pela noção de pessoa. Isto, segundo as lógicas do apego e do desapego que elas nutrem em sua relação ao legado deixado pelos seus antepassados a ser transmitido para seus descendentes.

Dentro da perspectiva das transformações sociais características das sociedades complexas e, singularmente, da sociedade brasileira (VELHO, 1987:17), a relação propriedade e 
poder se destaca como tema para pensarmos as representações simbólicas das minhas informantes quanto às condições de vida das camadas médias nos grandes centros metropolitanos e às possibilidades de descenso social, ambos fortemente ligados a posição social adquirida por elas no interior dos laços de parentesco por meio dos quais herdaram a "casa de família".

Inserido, portanto, nas discussões de uma antropologia do espaço e dos estudos de sociedades complexas, as formas de sociabilidade em família, como dimensões da vida urbana na cidade de Porto Alegre, tornam-se importantes categorias de análise nesse ensaio, visto que as transformações nos laços sociais oriundos da separação e da viuvez re-orientam o campo de possibilidades de realização dos projetos de vida dessas mulheres, nos últimos anos. A cidade e os bairros onde moram são o cenário das transformações de seu status social de solteira à casada tanto quanto em decorrência, no campo de estruturas de parentesco diversas - de suas famílias de origem, da família de origem de seu marido e da família de procriação por ela construídas pelo casamento (desde o nascimento dos filhos, dos netos, etc.) da viuvez ou do divórcio. Para cada um dos momentos rituais de composição e recomposição da vida familiar a intenção, com esta monografia, é retraçar algumas pistas dos papéis sociais de mulher, mãe e esposa e seus fundamentos morais para o estudo da construção social de sua figura como a guardiã-damemória familiar.

\section{Ser mulher, ser mãe}

\section{Percurso etnográfico: um percurso pelas representações de gênero}

Esta pesquisa se inaugura com o meu processo de entrada numa bolsa de iniciação científica em Antropologia social, junto ao Banco de Imagens e Efeitos Visuais, ligado ao programa de Pós-Graduação em Antropologia Social da UFRGS, com subvenção do CNPq.

Os relatos apresentados nesse ensaio foram frutos da minha experiência etnográfica com duas mulheres oriundas de famílias tradicionais porto-alegrenses, durante os anos de 2006 e 2007, sendo uma delas representante das grandes aristocracias locais, e que remonta a saga da imigração alemã para o RS.

Acompanhando o processo de desmonte de "casas de família", uma no bairro Tristeza, e outra, no bairro Rio Branco, minha intenção inicial era abordar as dificuldades das famílias com a mudança de residência, os motivos deste processo e a história da casa propriamente dita, desde o momento em que os moradores começaram habitá-la. Indicada ou por amigos ou conhecidos de amigos, a partir de uma rede de aproximação, acabei encontrando duas mulheres ${ }^{2}$ vivendo

\footnotetext{
${ }^{2}$ Optei por não usar os nomes e sobrenomes reais dessas mulheres e seus parentes nesse trabalho. Dessa forma, os nomes citados nesse ensaio são todos fictícios.
} 
processos distintos em relação à situação de pesquisa apresentada, diferença que tornou minha experiência etnográfica com famílias de camadas médias ainda mais rico.

Uma delas dessas mulheres, Anabela foi "deixada pelo marido", em meio ao processo judicial de partilha do terreno onde morava com ele e os filhos. O casarão construído em 1912, que ocupava parte deste terreno, e onde ela morava até a finalização das divisões, foi desocupado e parcialmente destruído, já que ficava entre duas partes das três parcelas do terreno dividas entre ela e os herdeiros legais. Vivendo hoje numa casa - composta de um quarto, um banheiro e uma sala - Anabela ainda divide o terreno com seus três filhos, sendo que dois deles já construíram suas propriedades de tamanhos equivalentes ao da moradia de Anabela, atrás da casa da mãe.

Fazendo limite com o rio Guaíba o acesso a casa de Anabela e dos filhos é feito por uma única entrada. Questionada sobre a venda desse terreno para a compra de outro imóvel ela sempre foi taxativa: "só saio daqui morta”, "nasci aqui, aqui a minha mãe casou e veio para cá, sempre aqui. Pode dizer que vale, não sei quanto, que eu não quero nem saber”.

Quando casada, Anabela morou em outras casas e apartamentos até voltar para a casa paterna com o marido e os filhos, a fim de cuidar do pai doente. A separação dos pais de Anabela no fim da década de sessenta, em razão da traição da sua mãe com um dos irmãos do seu marido (tio de Anabela), a afastou de um convívio com a avó paterna de quem herdou um estilo de vida aristocrático que ela insistentemente re-lembrava ao longo das conversas comigo. Conforme seu relato: "Aqui eu me lembro quando criança que eram servidos uns chás de muita pompa, sabe? Guardanapos de linho, sabe? Final de tarde”.

Anabela tem dois filhos homens e uma filha mulher, na época em que me deu os relatos aqui apresentados ela tinha cinqüenta e cinco anos. Professora aposentada do estado, seu casamento, como o de seu pai, não se deu dentro da etnia alemã conforme revela a genealogia dos laços de parentesco de suas famílias de origem - do lado paterno e materno. Um fenômeno recorrente desde que seus antepassados chegaram a Estância Velha e no Vale do Caí, respectivamente, em 1846 e 1847.

Carlota, por sua vez é viúva, mãe de duas filhas mulheres e um filho homem; todos, assim como os de Anabela, na faixa dos trinta anos. Tem cinqüenta e seis anos e descendência alemã por parte paterna, porém já na geração do seu avô o casamento étnico deixou de ser uma constante. Com uma trajetória social ligada a família e as opções do marido, intelectual de grande projeção na cidade de Porto Alegre, Carlota conheceu a casa onde morou por vinte e cinco anos quando ainda era jovem. Integrante de um estilo de vida de camadas médias de Porto Alegre, estudava no tradicional colégio Bom Conselho e passava o verão na casa dos pais, na praia de Torres, litoral norte do estado do Rio Grande do Sul. Foi lá, num desses verões, que 
conheceu as sete primas do seu futuro marido. Aproximada a rotina das novas amigas: de idas ao cinema; a bailes juvenis; e estadias na casa dessa família na serra; a casa estilo geminado no Bairro Rio Branco foi integrando o cotidiano de Carlota, assim como as relações com os primos das amigas, entre eles seu futuro esposo.

Seu casamento foi realizado na casa, construída em 1946 pelo pai da sua sogra como presente as duas filhas casadas, pouco antes de Carlota viajar ao Rio de Janeiro em função das atividades acadêmicas do marido. Opção que a fez abandonar na ocasião, suas tentativas de prestar vestibular. Em 1982, quando retorna à Porto Alegre definitivamente, ela e o marido eram os únicos dos quatro filhos da descendência paterna que não possuíam casa própria. A sogra, viúva desde 1974, resolve então em acordo com os filhos vender “num negócio de irmãos”, a casa da sua família para a família de Carlota e o marido, que era também um desses irmãos.

Após a morte do marido, nove anos antes da venda da casa, Carlota com a saída da vó - a sogra, que foi morar com um dos seus outros três filhos - e a saída dos filhos de casa, viu-se sozinha dentro do casarão. Apostou em reformas do espaço, pinturas e modificações nos cômodos, porém “a pressão" foi grande para a venda do patrimônio, pois além de sozinha na casa, a construção de estilo geminado deixava dispendioso para as primas do marido o sustento da outra metade da casa, vazia desde 2001, aproximadamente.

Na ocasião do trabalho de campo, prestes a concluir o bacharelado em Turismo, Carlota recebeu após dois anos de angústia a proposta de compra da casa por uma empresa de construção de prédios de apartamento para famílias de camadas médias e altas de Porto Alegre. Em comum acordo com a família do marido e com os seus filhos, eles vendem a propriedade. Dividindo o dinheiro conforme as porcentagens legais. Com esse dinheiro ela resolve adquirir outro imóvel, uma casa, porém em outra cidade que não Porto Alegre, desocupando o casarão em julho de 2007.

\section{Distinção, prestígio e status em jogo - a cidade}

Ao longo de alguns meses, nesses dois anos, minha inserção em campo se orientou para entrevistas semi-estruturadas e conversas com as moradoras das casas em processo de desocupação, em geral dentro do espaço de suas casas e sempre acompanhada de registro audiovisual, já que minha bolsa de iniciação científica se destinava a pesquisa com vídeo etnográfico dentro do BIEV.

Durante esse período acompanhei: as casas sendo desmontadas; a preparação das mudanças; a saída da casa e a instalação dessas mulheres na nova morada; sempre orientada pelo "método da observação participante" (MALINOWSKI, 1976) e onde o recurso ao registro 
audiovisual durante etnografia tinha, por intenção, a produção de um documentário que pudesse contar depois, por imagens, os percursos desse processo para as mulheres, cujas trajetórias e itinerários eu acompanhava, assim como a construção de um registro desse processo para as suas famílias.

O caráter "tradicional", "erudito" e "aristocrático" dessas famílias as quais pertenciam minhas interlocutoras foi sendo reconhecido aos poucos, ao longo do processo de análise das entrevistas, sempre não-diretivas (THIOLLENT, 1980). Nele pude perceber - pela profusão de sobrenomes citados - que todos eram eles importantes na construção de uma burguesia industrial (MERTZ, 1991:2) porto-alegrense assim como na formação do campo intelectual da cidade. À medida que a pesquisa de campo avançava, a dimensão da mudança da "casa de família", e sua posterior destruição, em termos do patrimônio material e imaterial do qual descendiam as formas de vida das famílias pesquisadas, ressaltava um processo de fechamento de ciclo que se iniciava na construção de uma certa cidade de Porto Alegre pelas mãos dessas famílias.

As casas onde essas mulheres moravam são construções que datam de 1912 e 1946, aproximadamente. Pensando essas datas a partir do contexto metropolitano da cidade de Porto Alegre, temos dois eixos importantes para pensar a cidade e a transformação dela conforme os ideários burgueses e o estilo de vida europeu da qual também compartilhavam essas famílias com a quais estamos dialogando.

Em 1912, Porto Alegre tinha aproximadamente 110.000 mil habitantes, era uma cidade de comércio ativo, possibilitado pelos colonos donos de pequenas indústrias familiares ou pequenos negócios ligados a agricultura. Em 1910 a via férrea "partindo do tronco Porto Alegre-Novo Hamburgo” (MERTZ, 1991:429) chega até Caxias, possibilitando maiores mobilidades no transporte da carga que antes era feito via porto de São Sebastião do Caí. Essas possibilidades, portanto, incentivavam cada vez mais, por parte do comércio da capital, o investimento no desenvolvimento e a transformação dessas pequenas indústrias e negócios familiares em grandes indústrias. Com financiamento desses comerciantes, aliados ao aumento significativo de bancos na capital, indústrias como a FIATEC e a empresa A. J. RENNER foram criadas respectivamente em 1891 e 1914, data que esta última inaugurou suas instalações na capital. Os bancos investidores e co-acionistas de muitas empresas não tardaram a criar novos bancos particulares, como possibilidade para os industriais e os comerciantes diversificarem seu capital aplicando-o no ramo da incipiente construção civil local.

Em meio essa prosperidade, e inspirado pelo ritmo de crescimento econômico acelerado, o intendente José Montaury encomenda em 1910, ao arquiteto João Moreira Maciel um Plano de Melhoramentos para a cidade de Porto Alegre. Lançado em 1914, o Plano Moreira Maciel 
transforma a cidade de Porto Alegre, que desde 1906 (DORNELLES, 1994:79) já convivia com a presença dos automóveis, com a inauguração das primeiras salas de cinema na Rua da Praia, e com as construções que embelezavam a cidade como os prédios dos Correios, na atual Siqueira Campos. Uma elite profundamente capitalizada enfeita suas casas com fontes e mausoléus.

Os ares da modernidade e do plano do Barão de Haussmann implantado em Paris em 1851 inspiraram João Moreira Maciel a criar uma Porto Alegre, que a exemplo do acontecido na capital da França, demoliria casarios simples na região do centro e da cidade baixa, extinguiria ruas e ruelas sujas e apinhadas, projetando avenidas de grande extensão e largura, inaugurando, sessenta anos depois de Paris, uma geometria de avenidas, viadutos, largos e passeios para Porto Alegre.

Conforme o historiador Charles Monteiro, o espaço urbano porto-alegrense e seus arrabaldes torna-se agente da transformação, pois através dele um novo regime de imagens se consolida pela nova ordem político-econômico-social na destruição e normatização das formas antigas. Construindo uma nova estética do viver comum, que legitima "novos valores burgueses que sustentam a nova ordem capitalista em expansão” (DORNELLES, 1994, apud MONTEIRO, 1992:19).

Os sítios de lazer na região da casa de Anabela e da qual seu antigo casarão era representante no bairro Tristeza serviram, por exemplo, até poucas décadas atrás, como recantos dessas famílias abastadas da cidade de Porto Alegre que, possuindo outras residências na região central, rumavam para a "praia" nos fins de semana a fim de praticar esportes náuticos e sociabilizar com a família.

Conforme o expediente urbano de Porto Alegre, do ano de 1942, (PAIVA, 1942:26) a cidade entre os anos de 1912 e 1946 teve um crescimento populacional de 110.000 mil habitantes para 300.000 mil habitantes. A década de quarenta, portanto, em relação às primeiras décadas, do ponto de vista dos espaços e ambiência da cidade, apresentava um panorama urbano já bastante diferente para Porto Alegre.

As indústrias locais, oriundas da fixação de famílias alemães na capital porto-alegrense, já solidamente instaladas tornam-se responsáveis pelo intenso processo de urbanização da cidade, rompendo definitivamente com os limites do centro e suas cercanias como local de moradia das famílias abastadas, que cada vez mais se expandem em direção contrária as margens do rio Guaíba, ocupando as áreas mais altas como Petrópolis, Caminho do Meio, Rio Branco, Mont'Serrat, etc. A casa que Carlota herda, após a morte do marido, foi construída por sua sogra e sogro num destes bairros. A enchente de 1941 foi, neste caso, alerta para os riscos que a cidade sofria com a aglomeração na região do centro. As vilas operárias iniciariam suas construções na 
década de 1950, porém o Plano diretor elaborado pelo urbanista Arnaldo Gladosch em 1943 estabeleceria um zoneamento viário (DORNELLES, 1994:57) inspirado nos planos do Rio de Janeiro e de São Paulo.

A abertura de avenidas, a exemplo da Avenida Salgado Filho, foi o resultado de todo este processo de migrações de famílias dos mais diversos segmentos sociais para distintas áreas da cidade, resultando disto a demolição de casarões, a destruição de cortiços, a construção de casas populares e bairros operários na região em torno da malha industrial (a Vila IAPI, é um dos exemplos), abrindo-se, ao mesmo tempo, o espaço urbano para construção dos chamados arranha-céus e prédios de alvenaria cujo número, em 1942, somava 50.000 em relação aos 14.000, de 1910 (PAIVA, 1942:120).

Bairros como o Petrópolis e o Rio Branco com a renovação e ampliação da malha viária começavam, portanto, a ganhar espaço dentro de um estilo de moradia burguesa com seus “residenciais nascentes" (PAIVA, 1942:67). As moradias de madeira, simples, as colônias de negros, os matagais, foram sendo tomados pelas mansões, casarões instalados dentro de grandes terrenos, residências de estancieiros vindos do interior do estado ou de uma burguesia comercial e industrial. Instaladas no alto de morros essas residências reinavam sob a vista de uma cidade em plena expansão, local privilegiado para uma vista panorâmica do rio, longe dos riscos que ele poderia trazer as suas propriedades. Segundo Paiva "as construções, nas zonas atingidas pelas enchentes é quase nulo; procura-se construir de preferência, nas partes altas” (1942:121).

Na década de quarenta, Loureiro da Silva ainda canalizou o dilúvio e construiu a ponte da Azenha, num ritmo de modificação da feição da cidade que já dava espaço para algumas lembranças, levadas pela melancolia do esquecimento de certas partes da cidade, que iam desaparecendo com as obras grandiosas.

O portoalegrense não saberá mais o que foi a subida de S. Jorge. Ninguém lhe dirá do destino dos riachinhos ativos que fizeram o desenho caprichoso do Dilúvio. E as avenidas que rasgam, todos os dias em todos os sentidos, nada lhe falarão da ruelas apertadas onde se levantou o sobradinho feio do antepassado barbaçudo e onde estão enterradas as raízes da sua ascendência” (FERREIRA, 1940:11)

\section{Distinção, prestígio e status em jogo - a casa}

Dentro desses diferentes contextos da cidade as casas das nossas interlocutoras são propriedades que ocupavam terrenos amplos e largos, contendo quintal, pátio, árvores, jardins, garagem. Uma das moradas situada a beira do rio Guaíba - bairro Tristeza - outra localizada no 
Bairro Rio Branco - região da cidade onde era possível se avistar as águas do Lago. Regiões preponderantemente ocupadas por uma elite empresarial e intelectual da época.

Os recursos metodológicos que estão sendo usados partem da observação participante (MALINOWSKI, 1976) de três momentos que integram o processo (TURNER, 1974) de desocupação da casa conforme exercício etnográfico já realizado junto a casas de família de camadas médias. As três etapas envolvidas na saída de um domicílio e a entrada em outro, são compreendidas a luz do trabalho de Arnold Van Gennep com os rituais: de separação, liminariedade e agregação onde se observa as marcações simbólicas e as particularidades de cada um desses momentos vividos por famílias de camadas médias. Buscando compreender a motivação a certas transformações e identificar os símbolos que no processo de transformação conciso nessa passagem, são operados. Nessa linha teórica, o rito de passagem de casa, será trabalhado, portanto, em três etapas: 1. A CASA COMO ERA; 2. O DESMONTE; 3. A MUDANÇA.

Em cada um desses aspectos da experiência (BRUNER \& TURNER, 1986) de mudar de casa se buscará entender, partido dos estudos de Arnold Van Gennep sobre os ritos de passagem, a casa e as "cerimônias de mudança de domicílio" (1978:38) como um ritual de "passagem material”.

A antropologia da imagem, ligada aos estudos teóricos e metodológicos sobre etnografia da duração, que vem sendo desenvolvidos pelo BIEV, tem permitido, neste estudo, situar estes momentos/etapas de um processo ritual (TURNER, 1974) como instantes importantes para se estudar os dramas sociais (BRUNER \&TURNER, 1986) que vivem estas famílias.

Pensar o sentido de um patrimônio ou bem imóvel na cidade, a partir da produção de imagens, é pensar os gestos e as formas dos seus habitantes se relacionarem com o mundo, a partir de determinados enquadramentos. Na orientação dos estudos de Claudine de France (1998) é preciso que esses enquadramentos mostrem, na relação do tempo da sua ação e do tempo da sua gravação, um esforço de explorar os sentidos que constituem os habitantes da casa na cidade.

As posturas e os gestos que compõe as imagens gravadas geram um tipo de interação entre pesquisador e interlocutor criando um espaço de conversa e entrevista que sugere outras questões e outras abordagens ao fenômeno estudado.

Seguindo Claudine de France, "o enquadramento de base” (1998:67) que tem orientado a coleta de dado está ligado "a delimitação espacial que coincide com o pólo de interação principal da atividade", seja ela uma situação de escolha de fotografias junto à pesquisadora e a sua câmera, seja nos percursos pelos espaços da casa que explorei em conjunto com minhas interlocutoras. Os itinerários presentes no momento da gravação e o deslocamento espacial 
concreto das interlocutoras, segundo a organização e relevância dos objetos dispostos na cena guiaram as minhas interações com elas no interior das casas, e é isto que sugere o enquadramento de base por mim adotado na produção de imagens em campo.

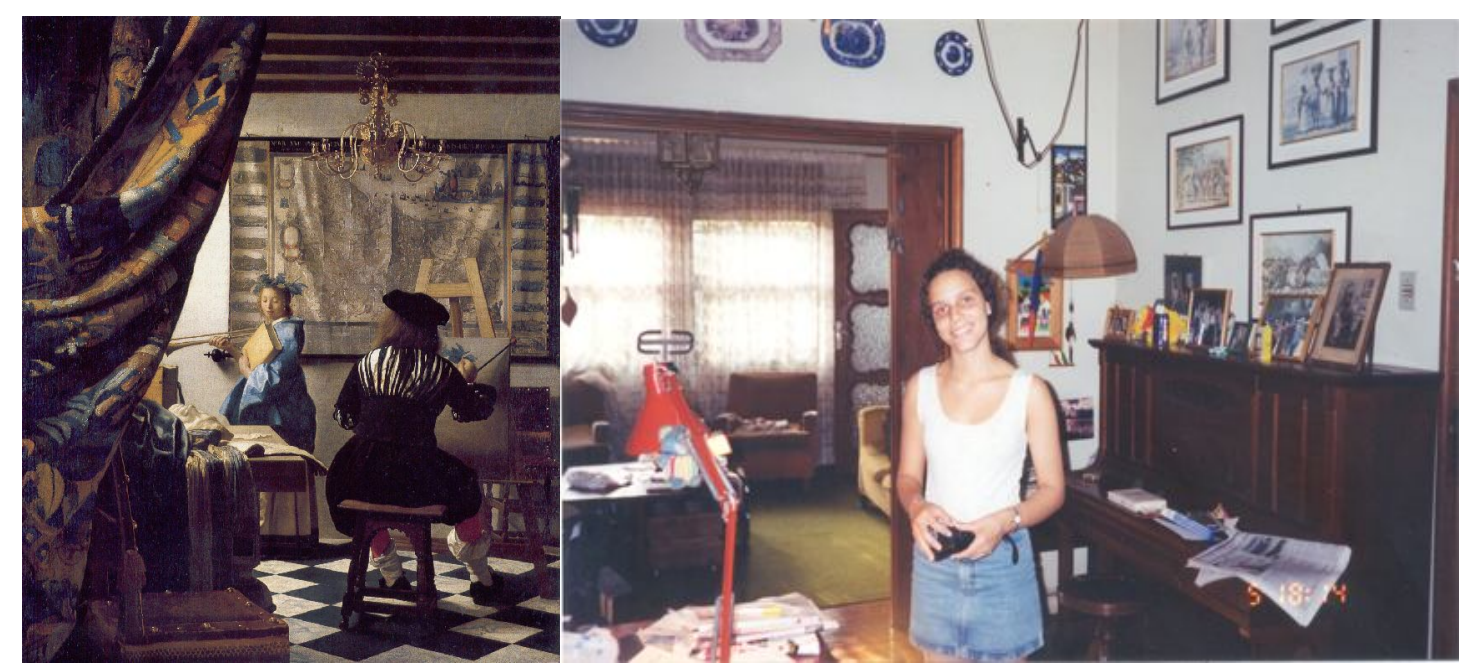

A observação desses espaços, a partir da análise das fitas gravadas e da transcrição das entrevistas feitas, foi fundamental para pensar a que ethos e visão de mundo minhas interlocutoras estavam se referindo quando me mostravam o interior de suas casas, assim como me auxiliaram a interpretar o conjunto das práticas e dos rituais familiares que ali foram realizados.

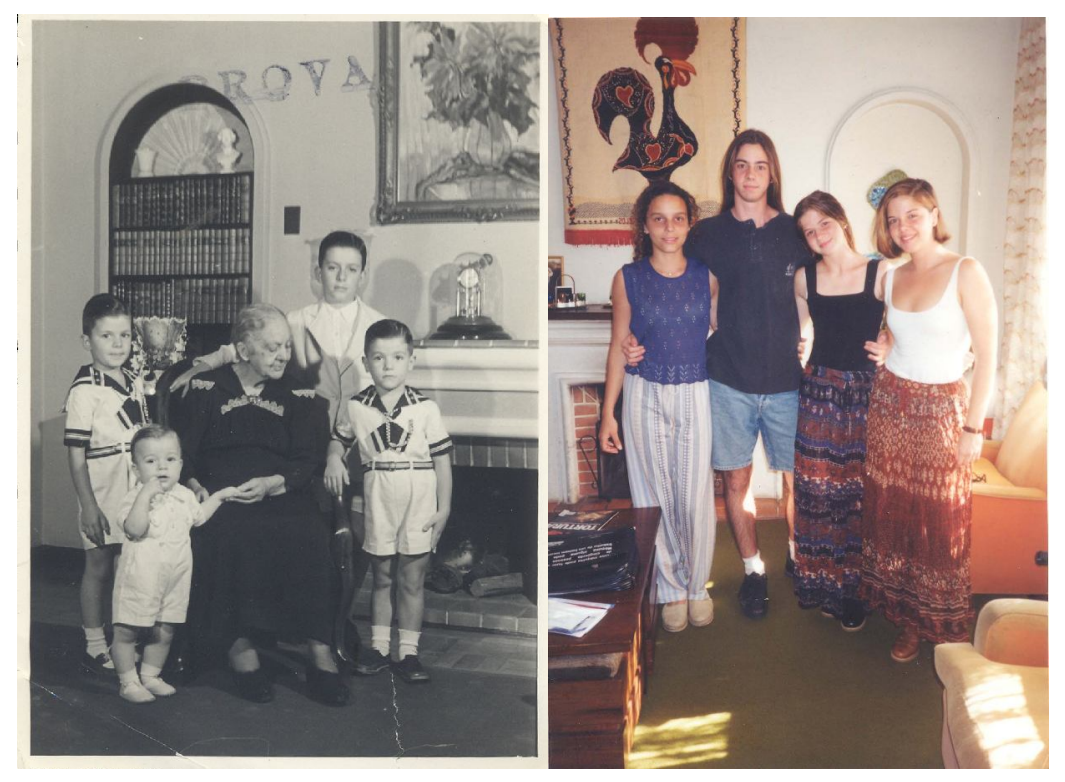

Conforme Ariès, antes do século XV as cenas no interior da casa são raras, com as representações mais freqüentes do quarto e da sala. Volta-se para a "intimidade da vida privada" (1978:204), chegando a uma "avalanche de imagens de família" no século XVI e XVII. Com 
influência dos pintores holandeses, as cenas cotidianas da família são retratadas como "cenas de gênero": "os homens reunidos junto à lareira, uma mulher tirando um caldeirão do fogo, uma menina dando de comer ao irmão" (1978:207).

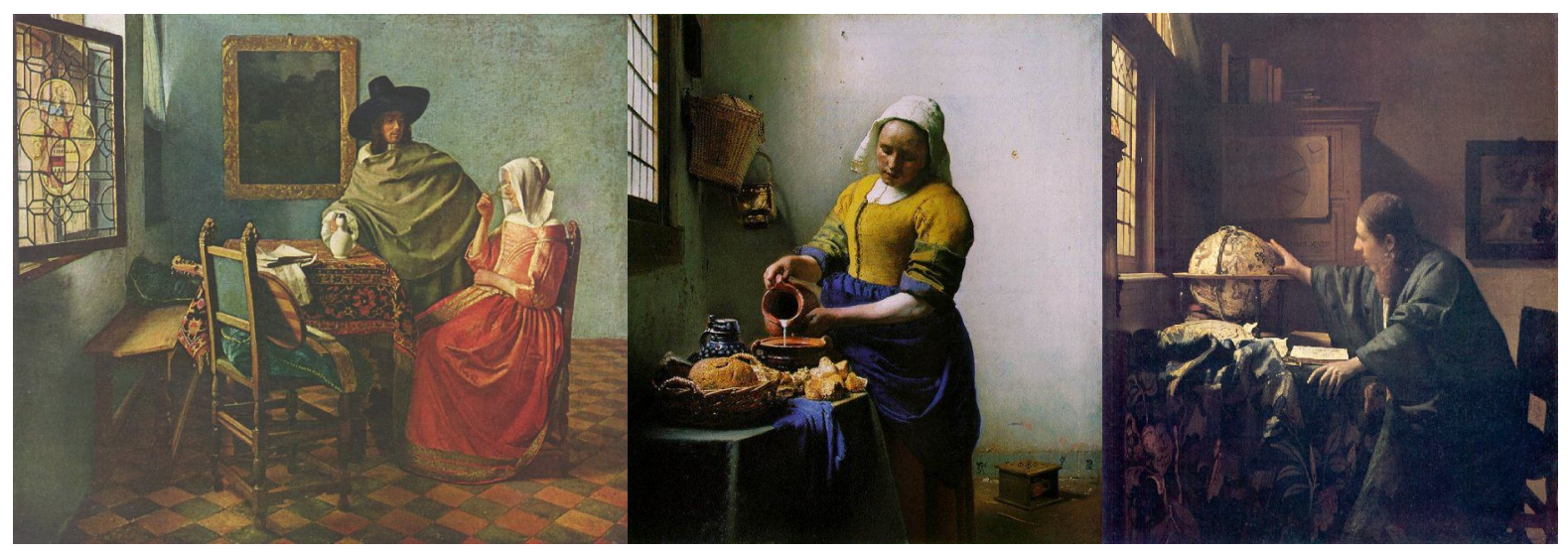

Da mesma forma, a medida que avancei no tratamento documental do processo de desmontagem da "casa de família", fui percebendo que o espaço da morada e as formas de sociabilidade que ali transcorreram ao longo do tempo era motivo de descrições detalhadas nos passeios que faziam por entre seus cômodos. Sempre eram destacados os móveis que compunham a decoração dos diferentes espaços, da sala de jantar aos quartos.

O que me fazia pensar constantemente na proximidade da morte dessas moradias, pois as casas estavam prestes a serem vendidas e demolidas, obrigando as duas mulheres a se mudar para casas muito menores. Uma delas, em particular - a herdeira da tradição de toda uma dinastia de famílias alemãs em Porto Alegre, de grandes empresários e industriais - iria reconstruir sua vida a partir da construção de uma outra casa, numa parte pequena desse antigo terreno, agora dividido, em partilha, com seu irmão.

Dessa forma, pela narrativa dessas mulheres - que descrevem e destacam "um certo" espaço da casa - percebi que a "casa da família" por elas herdadas e a ponto de desaparecer, se tornava testemunha de uma trajetória familiar, sua e a toda uma descendência, boa parte de origem alemã. Ele evidenciava a relevância de um patrimônio ligado a costumes europeus e um estilo de família burguesa européia, menos do que a um passado das pequenas empresas de banha ou ourivesarias iniciadas pelos primeiros descendentes da "árvore” das famílias (WOORTMANN, 1994), que desembarcaram no Vale do Caí, na metade do século XIX.

Como forma de pensarmos essa relevância, abaixo temos dois trechos de diálogos meus com Anabela e com Carlota. Eles nos remetem a relação com os bens móveis e objetos que ficam para além da casa e, portanto, importantes para pensarmos a partir deles na a transmissão e a herança dos valores familiares que eles representam e dos quais vínhamos falando. 
Carlota quando fala dos objetos que carregam história, fala de histórias ligadas a descendência parental do marido, estrutura da qual ela faz parte pela aliança de casamento e da qual a partir dessa aliança e pela ocupação dos espaços da casa, ela quer lembrar e transmitir. A conversa ocorreu um mês antes do processo de desocupação da casa da família:

\begin{abstract}
O meu casamento foi aqui. O meu casamento foi aqui. Fizemos a festa aqui, aqui era a sala de jantar tinha aquele balcão, tinha a cristaleira, mesa com as cadeiras, sala de jantar, que também não usava, só em ocasião especialíssimas.

Aqui era a copa e aqui é que eles viviam todas as refeições. (...) Tem um banco aqui, essa mesa fica com um banco aqui, e eu tenho foto de todos, os meus filhos eu criei ao redor dessa mesa, eu sempre digo isso e a mesa eu vou levar comigo. Porque eu criei meus filhos aqui, a gente nas refeições conversava, brigava eu fazia absolutamente questão de todo mundo junto durante muito tempo. Depois, no fim, eu tive que largar né. (...) a da vó nesse mesmo lugar ela levou, essa aqui eu comprei no rio. E ela tem trinta anos e ela não tem um cupim, ela é maravilhosa (...) exatamente a mesma posição só que a mesa é outra, eu tenho foto dos aniversários dos meus filhos em volta dessa mesa, de toda a vida né. Foto de aniversário de todo mundo eu tenho uns dois três álbuns só de gente ao redor dessa mesa a família se criou aqui.
\end{abstract}

Já a minha conversa com Anabela deu-se na pequena sala da casa nova dela, passado o período de mudança e construção da casa nova. Era a primeira vez que eu visitava essa casa "pronta":

Anelise: Qual foi a primeira coisa que entrou aqui?

Anabela: A primeira coisa? A cristaleira. A cristaleira e o balcão a coisa mais incrível. Eram as únicas coisas que eu tinha certeza de que, não, isso vai ficar aqui. Sabe? Esse espaço foi feito para ele. Para esse balcão.

Anelise: ah, tu já pensou nele...

Anabela: ahã...

Anelise: E por quê? Eles são do casamento?

Anabela: Meu?

Anelise: Não!

Anabela: Não! São do Frederico, né, meu bisa. É um valor...

No caso de Anabela, o lote de terra à beira do Guaíba, como já foi mencionado, outrora imenso e largo, foi repartido entre ela e seus filhos, que passaram a dividir com ela seu uso, construindo suas casas enfileiradas a casa materna. Observando o processo de ocupação atual do antigo terreno, vemos um processo evidente e claro de descenso social vivido por esta família ao longo do tempo, aproximando-os de uma condição de moradia muito semelhante a das classes trabalhadoras, onde em um mesmo terreno, há a casa da mãe - à frente - e aos fundos, em casas ainda menores, a moradia dos filhos casados.

Mesmo que, no caso de Anabela, a forma de moradia (da nova casa) possua essa aproximação com a forma de moradia de classes operárias e/ou trabalhadoras, "a casa própria" (FONSECA, 1997:7) permanece como valor que reúne o seu destino ao de Carlota. Já que na venda desses "casarões" herdados o dinheiro é revertido em outra moradia, garantindo a condição de "mais afortunados" em relação aos "outros", condição fundamental nas representações de status e prestígio para si mesmas e que essas mulheres estavam avaliando como risco possível na administração desse legado, face às gerações futuras (filhos e netos). 
Trabalhado e ressaltado por Claudia Fonseca (1997:10) as mulheres chefes-de-família são comuns desde o início do século XX no segmento das classes populares. Como bem alerta essa autora, "o recente aumento do número de famílias chefiadas por mulheres. Seja ligado, entre as camadas médias, ao movimento feminista e à nova autonomia da mulher" (FONSECA, 1997:26) não possibilita fazermos uma comparação superficial entre as duas condições de vida, a de mulheres de camadas médias e aquelas pertencentes às camadas populares. Entretanto, conforme a realidade aberta pela autora, transformações na estrutura dos papéis sociais em famílias de camadas médias são apontadas e aparecem no universo por mim pesquisado.

Porém, nos casos de Anabela e Carlota, que não se tornaram chefes-de-família em razão de movimentos feministas, e nem em razão da opção por um estilo de vida autônomo. Pelo contrário construíram seus papéis sexuais e de gênero dentro da clássica moral burguesa (dentro do casamento, em conformidade com os projetos de suas famílias de origem, na qual foram geradas), observamos os dramas do sustento da casa, do "ver-se sozinha no mundo" depois do fim de casamentos com mais de vinte anos de duração.

Ele era muito hábil com as mãos, muito, muito, muito. Ele era um super pesquisador, mas tinha uma habilidade manual incrível, tanto é que eu entre outras tantas coisas que eu senti falta dele, claro que é essa é muito menor, mas é a do faz tudo, ele fazia tudo: fio, cano, seja o que for, não tinha o que ele não resolvesse, ai quando ele morreu me vi mal, né, porque tu tem que achar o homem que é uma entidade, o homem do cano, o homem do fio e tu te quebra com com o homem.

Mas vê só, a casa do lado são sete filhos e o casal já morreu, eles moraram ai até o fim, faleceram, no ano passado faleceu, não, minto - acho que vão fazer dois anos em novembro - que faleceu a senhora que era irmã da minha sogra, a casa tá vazia, porque os filhos todos estão adiantados na vida, tem a sua casa e aqui o meu marido faleceu e os meus filhos casaram e eu fiquei só eu, então, não faz sentido entende? A vida dá voltas e não faz sentido a gente ficar com ela, infelizmente, só se eu ganhasse na mega sena, daí eu compraria as duas, faria uma pousada, como eu estudo turismo eu pensei: bah faço uma pousada aqui, faço um negócio legal, mas é irreal, não dá, eu tenho, eu não morro de fome, eu, eu tenho uma pensão, mas nada que eu possa manter uma casa dessas, então a gente está deixando, ela, ela precisa de pintura, tá, o telhado tem que dar uma olhada, ela tem cupim, ela tem não sei o que, e eu fui deixando, fui deixando e com muita dor a gente vendeu, mas... não tem como. (Carlota)

A vulnerabilidade de chefiar uma família, nesses casos, aparece mais pela moralidade imposta pela condição de viuvez ou separação perante a sociedade e menos pela tarefa de criação dos filhos, esse último apontado por C. Fonseca (1997) como uma condição freqüente na classe popular - e relacionada à condição de gênero nestes segmentos sociais.

$\mathrm{Ou}$ seja, no caso das minhas interlocutoras percebo uma vulnerabilidade fundamentalmente associada à manutenção de um estilo de vida originado no casamento, desde a saída da casa dos pais, onde a sua nova condição social, as confronta com o pagamento de contas, o conserto da casa, sem a ajuda do homem ou a presença masculina para assegurar seu sustento e suas decisões no âmbito do espaço público. 


\section{AS ESTRUTURAS DE PARENTESCO NAS SOCIEDADES COMPLEXAS MODERNAS CONTEMPORÂNEAS}

\section{Experiências particulares e universais}

Tendo em mente o contexto do estudo trazido por Claudia Fonseca através dos casos de apreensão de menores e disputas de guarda ${ }^{3}$ no juizado de Porto Alegre (1997:11), inspiramos no exemplo de Eutherpe, mencionada pela autora, para discutir o tema da mulher pobre no início do século XX, destacando a "moralidade oficial” que reflete os padrões burgueses de regulação do papel sexual da mulher na sociedade brasileira. Refletimos aqui sobre o sistema acusatório que pesa à situação da mulher que viola os "códigos de honra" que definem o masculino e o feminino dentro da família patriarcal, que a taxa freqüentemente de meretriz, de adúltera, ou de gênio difícil, no contexto das sociedades complexas-moderno-contemporâneas. Conforme G. Velho (1987:18) qualquer sociedade vive permanentemente a contradição "entre as particularizações de experiências restritas a certos segmentos, categorias, grupos e até indivíduos e a universalização de outras experiências que se expressa culturalmente através de conjuntos de símbolos homogeneizadores - paradigmas, temas, etc.”.

Dessa forma, no âmbito das sociedades complexas e da descontinuidade de seus universos simbólicos, o contato dos indivíduos pertencentes a determinados estratos sociais com outros segmentos, suas interações com redes de relações mais amplas afetariam sua visão de mundo e seu estilo de vida. Este processo introduz variáveis significativas para se pensar o tema da mobilidade social, do descenso ou da ascensão, de indivíduos e/ou grupos no interior de um segmento social ou entre eles, transformando por completo uma situação de "estabilidade $e$ permanência" que poderia haver em qualquer uma das classes, médias, populares ou trabalhadoras (VELHO, 1987:20).

Essa difusão e contaminação de paradigmas, portanto, aproxima, por uma situação de gênero, a trajetória da mãe de minha interlocutora, Anabela (vivido como herança moral por ela, sua filha), daquela de Eutherpe. Essa última, uma mulher que figura em um dos dossiês trazidos por Claudia Fonseca, sendo acusada pelo marido Joaquim a "adulterar-se" e, portanto, ser incapaz de ficar com a guarda dos filhos. Ambas, através e apesar, da sua diferente trajetória social viveram constrangimentos diante da sua condição de gênero no interior dos valores

\footnotetext{
${ }^{3}$ Além do caso de Eutherpe a autora traz outros, a partir de 148 dossiês que "passaram diante do juiz de órfãos entre 1901 e 1926" sobre apreensão de menores, disputas de guarda. Pessoas de "modos simples" que recorriam aos tribunais no início do século XX para reaver seus direitos. A partir de pequenas narrativas das trajetórias de mulheres e homem envolvidos em diferentes processos judiciais ou por acusação de adultério ou por reclamação de falta de condições de criação dos filhos a autora discute a condição feminina e a moralidade reguladora dessas condições.
} 
patriarcais ainda presentes nas grandes metrópoles contemporâneas do Brasil dos anos 40 e 50 . A mãe de Anabela - apesar de seu casamento tradicional, sua trajetória de ascensão social através dele, e sua adesão a um estilo de vida aristocrático herdado da família do marido pelo casamento - foi julgada como meretriz, assim como Eutherpe, por ficar com outro homem que não o seu marido. Os códigos de honra dos padrões burgueses, portanto, regulam para além de uma definição de classe social as trajetórias de mulheres, julgando seus papéis sexuais e sociais, e ameaçando sua prole de uma herança bastarda.

Anelise: e como foi a separação dos teus pais? Tu acompanhou tudo né?

Anabela: foi, foi uma coisa bem delicada. A mãe se separou por uma pessoa da família né. Um cunhado. Ela nunca negou, naquela época as mulheres eram julgadas né, os homens não. Mas as mulheres eram julgadas e ela foi considerada meretriz né. Nós prestamos depoimento, eu tinha 13 para 14 anos. A gente teve que dizer com quem iria ficar né. Na verdade eu queria ficar com meu pai, mas eu fiquei com ela porque eu sabia que ela que seria uma pessoa para me criar. Eu tinha noção disso, porque o pai era muito louco, o pai bebia né. Não tinha hora para voltar ele era uma pessoa inconseqüente né.

No caso da mãe de Anabela, concordamos com Claudia Fonseca "que há mais do que pressões econômicas levando a mulher a procurar um companheiro, e que o recasamento não conduz necessariamente à preservação do núcleo mãe-filhos” (1997:24), porém, arriscamos, ficam aos filhos as histórias herdadas da época das escolhas de suas mães. E mais do que as histórias, a experiência de circulação por outros lares, as transformações em seus cotidianos e as representações sobre as escolhas de suas mães, a partir da narrativa de si mesmos nesse exercício entre a "modéstia da manutenção do si e o orgulho estóico da inflexível constância a si" (RICOEUR, 1991 apud ECKERT e ROCHA, 1995:138).

\section{A casa e a família}

Tendo em mente o relato de Anabela sobre os motivos que a levaram a escolher a mãe para criá-la, nos aproximamos da imagem da mãe como imagem de estabilidade, conforto e segurança para pensar a "casa de família" em camadas médias urbanas. Pensamos a família conforme o trabalho de Claudia Fonseca (1995) sobre circulação de crianças em grupos populares, onde "uma consideração da maternidade em grupos populares tem, portanto, de levar em consideração também avós, criadeiras, e mães de criação” (1997:19) na estratégia para a sobrevivência das crianças.

Nesse sentido, destacamos o contexto - independente do laço de consangüinidade ou de uma "rede de ajuda mútua" - que evidencia a existência de uma casa, um teto, como elemento definidor da estada da criança. Pois mesmo no contexto de camadas populares onde algumas casas não passam de arranjos espaciais que lembram as acomodações do século XVII - salas 
onde: se comia, se dormia, se trabalhava e se dançava e onde o espaço das camas muitas vezes era fechada por cortinas (ARIÈS, 1986:260) - como descreve Ariès, era em torno dessas espaços que "estabeleciam-se círculos concêntricos de relações, progressivamente mais frouxos em direção a periferia: círculos de parentes, de amigos, de clientes, de protegidos, de devedores, etc.” (1986:262).

Portanto, mesmo num contexto mais amplo da definição de casa, pensamos que ela permanece como ancoradouro e garantia para a prática da circulação de crianças nas camadas populares: um lugar para comer, dormir e estar protegido, um lugar para se viver a família.

Próximo de uma definição do século XVIII de família moderna, e diferente do contexto de camadas populares, a casa de Carlota parece manter-se mais à distância da sociedade, confinando a família “a um espaço limitado”. Uma casa ampla, com corredores de acesso onde "mesmo quando os cômodos se comunicavam não se era mais forçado a atravessá-los para passar de um ao outro" (ARIÈS, 1986:265). O conforto segundo Ariès data do século XVIII "ele nasceu ao mesmo tempo que a intimidade, a discrição, e o isolamento, e foi uma das manifestações desses fenômenos". Oriunda de uma casa parecida com a de Carlota, Anabela vive hoje numa casa que lembra os arranjos do século XV, uma "instalação num meio mais amplo, a aldeia, a fazenda, o pátio”, porém em todos os casos, e simbolicamente por diferentes motivos, a casa, como espaço de proteção permanece no século atual como representação.

Para pensar essas diferenças e essa permanência da casa como espaço que agencia proteção, redes e relações de parentesco, vamos a três fragmentos, oriundos de diferentes contextos etnográficos e classes sociais. O primeiro retirado do texto: Ser mulher, mãe e pobre de Claudia Fonseca (1997:20), e os outros dois oriundos da minha pesquisa etnográfica com mulheres de camadas médias em Porto Alegre.

$(1 \mid)$

"(Alfredo V. declarou que) sua filha menor, Iris, desde que nasceu, viveu em companhia da sogra do declarante, isto porque moravam juntos, que depois que a esposa do declarante falleceu, a pedido da sogra do declarante, este a deixou na companhia della; que mais tarde sua sogra passou a residir em companhia do seu pai, Marcellino, para onde levou a filha do declarante, que tendo sua sogra fallecida, oito dias depois, o declarante foi a casa de Marcellino e levou sua filha para a casa de sua avó paterna, a mãe do declarante."

(2)

"Porque na verdade isso era uma coisa só né. Dai com a morte foram dividindo e foi ficando uma coisa diferente. Na verdade eu sou bisneta do que começou né

Ali é o Guaíba né, ali a ilha do presídio, ali o jangadeiros tirou a vista, mas a gente enxergava tudo ali, uma judiaria, mas é o progresso né...Não adianta

Anelise: E tu já pensou como vai ser agora, daqui para frente?

Anabela: Fica a mesma coisa.

Anelise: Mesmo sem a casa?

Anabela: Mesmo sem a casa. As pessoas foram passando, tem muitas coisas dentro dessa casa, assim as pessoas foram passando então assim tem muita magoa né. Tem muitas coisas aqui dentro dessa casa. Que eu acho ela vindo ao chão né... Mas o espaço ta aqui, a terra ta aqui, a vida continua. A gente também não é mais o mesmo. Quando cheguei aqui cheguei cheia de sonhos. 
Onde é que eu errei. Se eu perdi algo, não perdi né, eu ganhei, se tivesse que passar tudo de novo eu passava, porque eu fui muito feliz. E agora, é outra vida" (Anabela)

(3)

"Meu marido fez mestrado e doutorado no rio e a gente então morava lá - porque gente casou foi para lá e quando nós voltamos para porto alegre em 82, de todos os irmão deles só nós não tínhamos casa própria, porque a gente tava no rio, aquelas coisas... - então não tinha casa, ai nós começamos a procurar uma coisa para comprar, não tinha muito dinheiro e o que a gente podia comprar era um apartamento de dois quatros com o nosso dinheiro, e tinha dois filhos, três filhos já na época, e daí o pessoal começou "a vem cá porque vocês não ficam com a casa da mãe?”, até nós estávamos hospedados aqui para procurar casa né, então porque que não ficam com a casa da mãe? não sei o que, e como são quatro, então um quarto era nosso, um quarto a gente tinha em dinheiro e a outra metade a gente fez um financiamento e eles foram muito legais, foi coisa de irmão eles fizeram uma avaliação e normalmente essas avaliações são baixas né, e eles venderam exatamente pelo preço da avaliação. Foi um negócio de irmãos foram muito legais sem nenhum problema e gostaram porque a casa ficou na família, porque todos gostavam dessa casa e foram criados aqui. Então a casa continua na família." (Carlota)

Anabela, na sua infância e juventude, morou em quatro casas diferentes. Nasceu na casa do bairro Tristeza, depois da separação da mãe, ela e o irmão mais novo, foram morar com esta na casa da frente, comprada em razão da partilha de bens e pensão que o divórcio proporcionou a mãe. Depois numa casa no bairro Menino Deus e depois em um apartamento no bairro Higienópolis; importante reter que em seu testemunho Anabela salienta a importância de sua avó paterna em boa parte de sua infância. Já Carlota morou num sítio no bairro Passo d'Areia e depois no apartamento da família materna no bairro Independência. Estes itinerários urbanos remontados através de minha experiência etnográfica com tais famílias, dialogam com os itinerários de Iris no sentido destes obedeceram a certas linhagens de parentesco que determinam o local de moradia de jovens e crianças, conforme etapas vividas por seu núcleo familiar. No caso relatado por Alfredo, posteriormente a sua separação, sua filha desloca-se para morar em outro local, com a avó materna, criando-se assim uma circulação da criança no interior de uma lógica que subsidia os laços de parentesco, segundo os códigos ético-morais dos diferentes segmentos sociais. Em todos os relatos o personagem da casa se destaca e no provoca a uma associação da morada com a prole, mais do que à família. Em função dos cuidados que a prole representa para as relações de parentesco que definem as relações sociais com aqueles que as criam, e das quais herdaram um legado.

Dessa forma o espaço da casa agenciado pela construção da memória de Anabela, Carlota e provavelmente Iris (primeiro relato), nos permite pensar os laços de consangüinidade, os afetos, os dramas das relações familiares e, dessa forma, as diferentes concepções de família em jogo no espaço simbólico da morada (a "casa de família"). As regras que definem quem mora na casa, quem fica na casa, quem sai, podem ser definidas pelos tipos de aliança que as partes têm entre si. Conforme o estudo clássico de Lévi-Strauss a natureza é indiferente às modalidades das relações entre os sexos, “a natureza impõe a aliança sem determiná-la, e a cultura só a recebe 
para definir-lhe imediatamente as modalidades" (2003:71). No caso de uma pesquisa com camadas médias, a casa torna-se também um indício, a partir da aliança, para pensarmos a herança e o patrimônio familiar e sua duração no tempo.

\section{O patrimônio, herança e gênero - caso Anabela}

O legado dado pelo patrimônio inventariado que, no Brasil, segundo as leis de partilha e herança, na morte do cônjuge, são divididos entre a mulher (casada ou amancebada há mais de 5 anos, com o marido) e os filhos, coloca em pauta um dos dramas sociais envolvendo o risco de descenso social, perda de prestígio e status social envolvendo memória, família e as questões de gênero, e que integram a reflexão deste ensaio, em especial, no caso de famílias burguesas, detentoras de bens imóveis e possuidoras de traços aristocráticos em seus estilos de vida e visão de mundo.

Segundo Pierre Bourdieu (2007), o capital simbólico transmitido no "valor família" pode estar no estilo de vida e na visão de mundo que se quer "passar aos filhos", ligado a educação, aqui no caso, nos moldes "do sentimento moderno da família”, apontado por Philippe Ariès (1986: 277). Pode ser um legado ligado à manutenção de certos objetos de decoração ou móveis, que por estarem a anos na família, são repassados dentro da estrutura de parentesco de forma a reforçar certas lembranças de um tempo passado, que condensa a vida vivida pelos seus antepassados. No caso das famílias de descendentes de imigrantes alemães, como trabalha Ellen F. Woortmann (1994:3), esses objetos podem reforçar um passado "heróico ou heroicizante”, onde "a memória faz a descendência e a descendência faz a memória”.

\footnotetext{
Anabela: espaço, eu sou uma pessoa que precisa de espaço, eu preciso plantar eu preciso, ó, ouvir esse som, eu preciso. Certamente, se fosse necessário né... tanto que não vendi né. Que todo mundo achou que eu ia vender isso aqui né. Acredito que até os irmãos. Anelise: é?

Anabela: eu acho. Acredito que ninguém imaginou que eu ia permanecer aqui né.

Anelise: e o que que fez tu permanecer?

Anabela: ahhhh. Eu nunca pensei em não permanecer. As raízes né. O amor pelo lugar. Tu vê meu pai nasceu aqui, morreu aqui né.
}

As raízes que fala Anabela são relevantes, principalmente no caso da sua família ${ }^{4}$ pois nela a maioria dos bens móveis e imóveis de que são objetos das partilhas entre os herdeiros fazem parte de uma época heróica da trajetória de famílias alemãs para a paisagem urbana de Porto Alegre. É no interior deste processo que Anabela aparece como uma das principais

\footnotetext{
${ }^{4}$ Acostumadas a riscos, essas famílias eram detentoras de bancos e integrantes de associações de classe que inclusive foram patrocinadores dos revolucionários da Revolução de 1930, se envolvendo em cargos políticos ou com intenções políticas (PESAVENTO, 1986) a fim de manter suas fabricas em atividade, e com isso, garantir a manutenção do seu patrimônio ligado a bens móveis e imóveis.
} 
guardiãs-da-memória familiar, tendo que agenciar o deslocamento de objetos herdados de seus antepassados (seus e das famílias de seus maridos) no momento da decisão da destruição do bem imóvel e da mudança de residência.

\footnotetext{
"Ali tudo a mesma coisa como era. Te lembra?

Anelise: lembro.

Anabela: Tudo a mesma coisa né. Só que eram mais móveis né. Tem uns que eu optei, por exemplo, essa mesa ficou muito grande para esse ambiente né. Mas era uma mesa assim que eu ganhei do meu dindo, né, do irmão do pai.

(...)

Anelise: e a vó Catarina onde foi parar?

Anabela: ah. Ela ta guardadinha porque eu vou ter que mandar fazer um. Tentei mandar fazer, mas eles não fazem assim...

Anelise: uma moldura.

Anabela: é uma moldura, então vou ter que fazer... é bem... Aqui tu não olha essas coisas que tão aqui em cima, que eu to fazendo cópia. Lá ó, tu viste como tudo ficou pertadinho. Aquele móvel também é um móvel bem antigo. Esse na,o esse não, esse não era da família, é aquele lá né.
}

Neste sentido, o "valor família" e os fundamentos morais do gênero feminino (dedicação, distinção, elegância, etc), portanto, ligados ao casamento entre etnias alemã em ascensão foi sempre ressaltado nas minhas conversas com essas mulheres, principalmente com Anabela que inúmeras vezes me perguntava se eu estava casada ou namorando, muito curiosa em saber como eu sobrevivia e me sustentava. “Ah, mas tu vai achar" dizia ela sempre que ouvia a minha resposta negativa a sua pergunta sobre meu estado civil.

Quando eu fumava no pátio da casa, no intervalo do carregamento da mudança - ato que parei de fazer depois que percebi que isso me afastava do papel social da mulher para essa interlocutora e, portanto, me afastava de algumas trocas com ela - Anabela me dizia "ah para com isso, menina, isso é feio”, “o Carlos, detesta mulher que fume, nem deixa ele te ver” se referindo ao filho mais velho, do qual, inúmeras vezes ela tentou insinuar uma aproximação amorosa. Essa sua intervenção me lembrou do velho costume de "arranjar casamento" do qual a sua avó paterna tinha sido alvo e da qual ela me contara em nossas conversas:

\footnotetext{
Anabela: ela tinha 13 anos. Contou para minha mãe. E ai, ele achava ela muito bonita né. Minha vó tinha os olhos violeta né, que nem da Elizabeth Taylor. Ele com olhar brejeiro né, disse quando tu cresceres eu vou... (...) Quando tu cresceres eu vou casar contigo. E quando ele pediu ela em casamento, para o meu bisa no caso né, ele chamou a minha vó para comunicar né, o que ela achava daquele pedido, ela disse que já sabia. Claro ela guardou aquilo né.
}

Além disso, a insistência de Anabela me chamou atenção à medida que íamos estreitando os laços e que eu ia ficando mais próxima da memória familiar que ela visava guardar e da qual eu participava pela etnografia do processo de mudança da casa, na cumplicidade de gênero que mantinha e aprofundava nossas conversas e da qual percebi estava ligada ao papel da mulher como "guardiã da memória” (LINS DE BARROS, 1989) da família. 


\title{
O patrimônio, herança e gênero - caso Carlota
}

As mudanças de sorte (ELIAS, 1998) nas trajetórias sociais de Anabela e Carlota nos propõem a pensar, a partir da idéia de campo de possibilidade (SCHUTZ, apud WAGNER, 1979), qual o projeto de vida que elas constroem como alternativa para a manutenção de seu antigo estilo de vida e visão de mundo tendo em vista os desafios da destruição de seu antigo status social na família de origem, e tendo em vista o casamento como valor moral para a estrutura de parentesco com a qual encontram-se comprometidas, na condição de guardiãs-damemória.

Nos relatos organizados por Míriam Moreira Leite (1984) no livro A Condição Feminina no Rio de Janeiro no século XIX o de R. Walsh, de 1828, fala da administração de uma fazenda por uma mulher viúva numa descrição cuidadosa do corpo da mulher e da sua relação com a criadagem:

"Embora não se tratasse de pessoa musculosa, parecia grande e descuidada - apeava como homem, diante de nós, sem o menor acanhamento - bebeu um copo de cachaça na venda, para se fortificar contra o ar da montanha - tornou a montar, examinou as pistolas para ver que estava tudo certo para qualquer eventualidade e partiu de novo, protegendo a si mesma" (apud LEITE, 1984:57)

Numa das conversas com Carlota na sala do seu casarão, em meio a algumas caixas de papelão já previamente lotadas de utensílios e objetos pequenos, que se empilhavam no chão junto à parede laranja ela me relata:

\begin{abstract}
Minha vida deu muita virada, minha vida deu muita virada, e o fato de eu ter voltado a estudar para mim foi um recomeço e eu acho que os recomeços são bons, eu não gosto de gente que fica presa no passado, acho insuportável, eu podia passar o resto da vida chorando porque eu adorava o meu marido, mas foi difícil, não foi fácil, não é fácil, não foi, não é fácil, fiz terapia, fiz isso, fiz aquilo, mas eu luto para ir para frente. Porque eu acho até em consideração a ele, até, que lutou tanto pela vida e não venceu o câncer, mas lutou hein, que eu to viva tenho mais é que valorizar né. E eu acho que é válido, a gente não deve ficar preso ao passado de jeito nenhum, tem que ir para frente, tem que ir para frente e as mudanças fazem bem, as mudanças renovam a gente senão tu vai ficando muito azeda. (...)então é legal minha vida tá presa a essa casa, tenho muita coisa com ela mas, vai ser bom, espero que seja bom, to fazendo uma virada assim, mais uma vez, mais uma vez monumental, porque eu não to só saindo daqui né, eu to indo embora daqui.
\end{abstract}

Buscando unicamente enriquecer o universo das mulheres "chefes" e não estabelecer uma comparação entre os dois casos, observamos que o primeiro relato tratando-se do estranhamento de um homem ao ver uma mulher assumir o papel sexual de um homem frente a sua viuvez e as necessidades de gerenciamento da propriedade herdada, se dá no espaço público e provavelmente se restringe a ele mais do que ao espaço íntimo da casa. Mesmo tendo visto Carlota agir destemidamente frente aos "homens da mudança", "empreiteiros", "carregadores" ela o fez no espaço da sua casa. 
As mulheres desses dois relatos não estão vivendo constrangimentos de "viver às custas do marido", ou de precisarem da ajuda dos filhos para o sustento. Elas aparecem construindo a si como sujeito autônomo. Porém a primeira arca ao ser definida por um homem com o ônus da subversão dos papéis sexuais da mulher na sociedade. À medida que a última reflete sobre si mesma, sobre a questão do seu apego a uma idéia de família que a morte do marido finalizou e que ela questiona qual seria a melhor forma de recomeçar, para além da casa onde casaram e viveram, para além da sua condição de mulher casada. A escolha por ir embora reforça o desapego, o esforço para se reconstruir, a partir de outros papéis que mantenham um estilo de vida e uma visão de mundo que ainda lhe são caros. E que a ainda legitimam o seu projeto individual e familiar já que aparecem num esforço de "fragmentação-totalização" nas suas experiências narradas (VELHO, 1987:26).

\section{Considerações finais}

Casada com um homem fruto da união de uma grande família de descendentes alemães estabelecida em Cruz Alta com a de importantes estancieiros locais, Carlota, como Anabela, descendem de uma família da aristocracia rural rio-grandense, com grandes propriedades, prestígio e poder local. Carlota tem o avô materno, ligado a fundação da Cia. Varig, e o paterno, ligado ao setor do comércio, e tanto os lados, materno e paterno da família de origem do marido, tornaram-se parte das camadas médias intelectualizadas e eruditas da cidade de Porto Alegre.

Dentro desta trajetória social marcada pelo privilégio, abundância e riqueza, Carlota, no entanto, concluiu a faculdade só depois da morte do marido, o que, segundo Gilberto Velho, dentro do seu campo de possibilidades, era algo só possível de ser esperado após a criação dos filhos (liberada de seu papel nutriente no interior da família de procriação) e que, acoplado com a morte do esposo, acaba por se configurar, segundo seu relato, em mais uma das "viradas" da sua vida.

\footnotetext{
"Vou para casa. Vou para casa. Isso que eu tava falando, eu questiono muito a minha maneira de ser, o meus pensamentos acho que todo mundo é assim né? Eu pensei, meu deus até onde eu não estou sendo teimosa de me encazinar de ir para apartamento, mas eu fico tão infeliz num apartamento, eu acho tão horrível e ai eu não sei pode ser que eu seja louca, mas eu não gosto de apartamento entendeu? Eu morei na casa a vida inteira entendeu, por exemplo, um domingo eu não sou de sair assim todos os domingos, mas um domingo em casa é beleza, mas um domingo em apartamento eu vou morrer, eu tenho que sair, em casa é muito diferente, eu estou acostumada eu vou para o pátio o, aqui tem piscina, no verão vou para piscina, ou limpo a piscina ou sento aqui na frente no meu degrauzinho entende? Mas num apartamento ai! Ai, eu cheguei ao ponto de, se eu não posso morar numa casa em Porto Alegre, eu mudo, foi isso que eu pensei e foi isso que me levou eu ir para Canela. Claro que tem coisas, que o turismo lá bom, e ainda não to com trabalho lá, mas tenho muitos contatos, espero conseguir e também tenho uma filha que mora lá, minha filha é medica , mora em Canela, mora em Gramado e trabalha em Canela é lógico, e também, essa minha sogra aqui, esta minha sogra (ri), a minha sogra tem uma casa em Gramado, onde a gente passou todas as férias de julho, eu ia para lá com toda essa criançada, não só os filhos como os sobrinhos. Então a gente tem muita ligação. Vou para lá a vida inteira não to indo para um lugar desconhecido a única
} 
coisa que é muito diferente que eu sou nascida em Porto Alegre, criada, casada a vida inteira aqui e morar lá é uma coisa diferente, eu não sei"

Já Anabela não opta por ir embora, ela prefere ficar junto às "raízes", a "terra", a história e ao legado dos pais que não está em nenhum lugar para além do seu sobrenome, dos móveis e objetos herdados e do status de pertencer a uma família tradicional da cidade, com uma infância de dotes e bons costumes. Reforçada pelo "sempre estive aqui" a escolha de ficar, mesmo atrelada a uma condição de moradia que evidencia seu descenso social a preocupação de Anabela parece estar muito mais condicionada ao bairro, ao espaço de circulação que ele permite, ao ethos de habitante da zona sul da cidade. Ficar reforça os laços de descendência paterna de Anabela, reforçando para além da sua aliança de casamento, seu projeto ligado à estrutura de parentesco, lugar onde ela construiu sua história de vida. Já Carlota nas particularidades e generalizações de reconstrução do seu projeto familiar a partir de um projeto individual conseguir conforme Norbert Elias (1998) um maior “distanciamento” da situação de mudança de casa, optando apesar de todos os dramas e medos, ir viver num lugar onde pudesse manter ou onde não sentisse tanto descenso no seu estilo de vida. Pensando na linhagem a partir da herança e das gerações, o patrimônio que deixará Carlota aos seus descendentes está muito mais próximo do que seu pai deixou para ela, do que o patrimônio que Anabela deixará para seus filhos em relação ao que herdou dos seus pais. Dessa forma, pensar as estruturas de parentesco através da herança e do patrimônio é uma forma de pensar as mobilidades das condições de gênero, relações familiares e classe social numa sociedade complexa-moderno-contemporânea.

\section{Índice de imagens}

Imagem 1 - Reprodução de Alegoria da pintura (1666-1667), óleo sobre tela, de Johannes or Jan Vermeer - http://www.rijksmuseum.nl/

Imagem 2 - Fotografia do acervo pessoal de Carlota, cedida gentilmente para a pesquisa etnográfica, aproximadamente de 1995

Imagem 3 - Fotografia do acervo pessoal de Carlota, cedida gentilmente para a pesquisa etnográfica, aproximadamente de 1949

Imagem 4 - Fotografia do acervo pessoal de Carlota, cedida gentilmente para a pesquisa etnográfica, aproximadamente de 1995

Imagem 5 - Reprodução de Homem, mulher e vinho (1658-1661), óleo sobre tela, de Johannes or Jan Vermeer - http://www.rijksmuseum.nl/ 
Imagem 6 - Reprodução de A leiteira (1658-1660), óleo sobre tela, de Johannes or Jan Vermeer - http://www.rijksmuseum.nl/

Imagem 7 - Reprodução de $O$ astrônomo (1668), óleo sobre tela, de Johannes or Jan Vermeer http://www.rijksmuseum.nl/

\section{Referências}

ARIÈS, Philippe. História Social da criança e da família. Rio de Janeiro: Guanabara, 1986.

BACHELARD, Gaston. A poética do espaço. São Paulo: Martins Fontes, 2005.

BACHELARD, Gaston. A dialética da duração. São Paulo: Ática, 1988.

BRITES, Jurema. Afeto e desigualdade: gênero, geração e classe entre empregadas domésticas e seus empregadores. Cadernos Pagu, Unicamp, 2007.

BOURDIEU, Pierre. A distinção - Critica Social do Julgamento. Porto Alegre: Editora Zouk, 2007.

Edusp, 1998. A economia das trocas lingüísticas: o que falar quer dizer. São Paulo:

DORNELLES, Beatriz. Porto Alegre em destaque: História e Cultura. Porto Alegre: Ed. PUCRS, 1994

DURAND, Gilbert. As Estruturas Antropológicas do Imaginário. São Paulo: Martins Fontes, 2002.

ECKERT, Cornelia \& ROCHA, Ana Luiza Carvalho da. O tempo e a cidade. Porto Alegre: Editora UFRGS, 2005.

ELIAS, Norbert. Envolvimento e Alienação. Rio de Janeiro: Bertrand Brasil, 1998.

GEERTZ, Clifford. A interpretação das Culturas. Editora LTC, 1989.

FERREIRA, Athos Damasceno. Imagens sentimentais da cidade. Porto Alegre: livraria do Globo, 1940.

FONSECA, Claudia. Caminhos da adoção. São Paulo: Editora Cortez, 1995.

FONSECA, Claudia. Paternidade brasileira na era do DNA: a certeza que pariu a dúvida. Cuadernos de Antropologia Social 22.

FONSECA, Claudia. Da circulação de crianças à adoção internacional: questões de pertencimento e posse. Cadernos pagu (26), janeiro-junho de 2006: pp.11-43.

FONSECA, Claudia. Quando convergem tecnologia, lei e família: pensando questões de gênero e geração em conexão com testes de paternidade. No prelo.

FONSECA, Claudia. Ser mulher, MÃE e pobre: Trajetórias femininas do início do século xx. In História das Mulheres no Brasil (Mary DelPriore, org.). São Paulo: Editora Contexto, 1997.

FRANCE, Claudine de. Cinema e Antropologia. Campinas, SP: Editora da UNICAMP, 1998.

HALBWACHS, Maurice. A memória coletiva. São Paulo: Centauro, 2006.

HARRIS, C. C. The Family an introduction. London: George Allen and Unwin Ltd,1983.

JELIN, Elizabeth. Víctimas, familiares y ciudadanos/as: lãs luchas por la legitmidad de la palabra. Estudos Feministas Ano $31^{\circ}$ semestre de 95.

LÈVI-STRAUSS, Claude. As estruturas elementares do parentesco. Petrópolis: Ed. Vozes, 2003.

MALINOWSKI, B. Argonautas do Pacífico Ocidental. São Paulo, Abril Cultural, Pensadores, Atica, 1976.

MAUSS, Marcel. Sociologia e Antropologia. São Paulo: Cosac Naify, 2003.

MERTZ, Marli. A burguesia industrial gaúcha e suas tentativas de organização: de suas origens a 1930. Ensaios FEE, Porto Alegre, (12) 2: 422-444, 1991.

LEITE, Miriam Moreira. A condição feminina no Rio de Janeiro, Século XIX. São Paulo: Editora Hucitec, 1984. 
LINS DE BARROS, Myriam. "Memória e Família". In: Estudos Históricos 3, Memória. Rio de Janeiro, vol. 2, n. 3, 1989.

MOTTA-MAUÉS, Maria Angélica. De casa em casa, de rua em rua...na cidade: "circulação de crianças", hierarquias e espaços sociais em Belém. Trabalho apresentado na $26^{\mathrm{a}}$. Reunião Brasileira de Antropologia, realizada entre os dias 01 e 04 de junho, Porto Seguro, Bahia, Brasil, 2007.

MOTTA-MAUÉS, Maria Angélica. Uma vez “cria”sempre “cria”(?): Adoção, genero, e geração na Amazônia. $13^{\circ}$ CISO - Encontro de Ciências Sociais Norte e Nordeste 03 a 06 de Setembro de 2007, UFAL - Maceió (AL).

NOVAES \& SALEM, Simone \& Tânia. Recontextualizando o embrião. Estudos Feministas Ano $31^{\circ}$ semestre de 95.

PAIVA, Edvaldo Pereira. Expediente Urbano de Porto Alegre. Porto Alegre: Prefeitura Municipal, 1942.

PESAVENTO, Sandra. Empresariado Industrial, trabalho e estado - contribuição a uma análise da burguesia industrial gaúcha (1889-1930). São Paulo, USP (tese de doutorado), 1986.

ROCHA, Ana Luiza C. da. A dialética do Estranhamento - a reconstrução da identidade social de mulheres separadas em Porto Alegre. Dissertação de mestrado, UFRGS, 1985.

SALEM, Tania. O velho e o Novo - Um estudo de papéis e conflitos familiares. Petrópolis, Ed. Vozes, 1980.

SALEM, Tania. O casal grávido - Disposições e dilemas da parceria igualitária. Rio de Janeiro, Editora FGV, 2008.

SEGALEN, Martine. Qual é a Antropologia do parentesco e da família no século XXI? Um diálogo franco e brasileiro com Martine Segalen. Horizontes Antropológicos, Porto Alegre, ano 4, n. 8, p. 182 - 198, junho de 1998.

SIMMEL, Georg. Questões fundamentais da sociologia. . RJ, Jorge Zahar, 2006.

THIOLLENT, Michel. Critica metodológica. Investigação social e enquête operária. São Paulo: Polis, 1980.

THOMPSON, Charis. Making Parents - The ontological Choreography of Reproductive Technologies. London: The Mit Press, 2005.

TURNER, Victor. O processo ritual - Estrutura e Antiestrutura. Petrópolis: Vozes, 1974.

TURNER, Victor e BRUNER, Edward. (orgs) The Antropology of experience. ILLINOIS UNIVERSITY, 1986.

VAN GENNEP, Arnold. Os ritos de passagem. Petrópolis: Vozes, 1978.

YNGVESSON, Barbara. Parentesco reconfigurado no espaço da adoção. Estudos Feministas Ano $31^{\circ}$ semestre de 95.

WAGNER, Helmut R. (Org. e Introdução). Fenomenologia e relações sociais. Textos (escolhidos de Alfred Schutz. RJ, Zahar, 1979.

WOORTMANN, Elle F. A árvore da memória. Brasília, Série Antropologia 159, 1994. 